\title{
ANALYSIS OF ACTIVE PHARMACEUTICAL INGREDIENTS AND ANTIOXIDANT POTENTIAL OF WESTERN GHAT MEDICINAL PLANTS
}

\author{
SG. Funde \\ Department of Chemistry, Savitribai Phule Pune University, Pune, India.
}

\begin{abstract}
Traditional medicine is very popular medicine system from last decade and in future because of their beneficial effects against various diseases. It is mainly formulated from one or more than one plant parts. Various plant extracts were screened for total Polyphenolics, Flavonoids tartaric ester and antioxidant properties. Maximum content of poly phenolics are found in Dendrophythoe falcate and Adhantoda zeylanica 22.43and $19.27 \mathrm{mg}$ of gallic acid/gm of dry weight of medicinal plant materials. Maximum Quercetin content found in Acorus calamus, Fiscus religiosa 672.5 and $566.98 \mu \mathrm{g} / \mathrm{gm}$ of sample. Higher Naringin contents found in Acorus calamus, Fiscus religiosa Tridux procumbens; 700.5, 590.9 and 408.76 $\mu \mathrm{g} / \mathrm{gm}$ of sample. Antioxidant activity by ferric reducing antioxidant potential is higher in Syzgium cuminii L, Wthanic somanifere, Acmella oleracea, Lagenaria siceraria, Acorus calamus L. 713.331, 119.33, 99.110, 80.661 and $75.20 \mathrm{mM} / \mathrm{gm}$ of sample. High radical scavenging and phosphomolybdate antioxidant activity found in Dendrophythoe falcate and Acorus calamus plant extracts
\end{abstract}

Keywords: Antioxidant, medicinal plants, polyphenolics, FRAP and Flavonoids.

\section{INTRODUCTION}

Antioxidant are compound that inhibit or delay the oxidation of other molecules by inhibiting the initiation of propagation of oxidizing chain reaction involved in living as well as nonliving ${ }^{1}$. There are two basic categories of antioxidants namely endogenous and exogenous antioxidants. Exogenous antioxidants are having natural and synthetic occurrence ${ }^{2}$. In general, synthetic antioxidant are compound with phenolic structure of various degree of alkyl substation where as natural antioxidants are plant secondary metabolite which can be polyphenolics compound (chalcone, tartaric easter, anthiocynin, tocopherol, Flavonoids and polyphenolic acids ) nitrogen compound (alkaloids chlorophyll derivatives, amino acids and amines) as well as carotinoids ${ }^{3,4}$. Natural antioxidant had tremendous biological applications like anticancer antidiabetic anti CVD anti HIV anti protozoal antimicrobial etc. as compare to the synthetic antioxidants ${ }^{5,6,7}$. Previous reports suggest that traditional medicinal plants are the good source of natural antioxidants.

Generally plants contains secondary metabolite get vary from one region to other region observed in some species. Such change is responsible due to variation in of climate type of soil water stress and other environmental factors. These environmental factors are responsible for the change in primary and secondary metabolite biosynthesis and biotransformation ${ }^{8}$. Variation in natural product may responsible in change in formulation of ayurvedic medicine. The present study elaborates on the chemical composition of medicinal plant as well as on the total antioxidant activity of methanol extract.

\section{MATERIAL AND METHODS \\ 2.1 CHEMICALS}

Methanol (MeOH), Himedia, Quercetin, Caffeic acid, Catechin, Gallic acid, Ascorbic acid, Quercetin, Naringenin, Naringin, Rutin, Epigallactocatechin, Curcumin, Hydrochloric 
acid $(\mathrm{HCl})$, Ferrous sulphate(FeSO4), Sulfuric acid(H2SO4), Sodium phosphate, Ammonium molybdate, Ammonium ferrous sulphate (NH3(FeSO4)), Trolox, Diphenyl picryl hydrazine (DPPH), Ferric chloride $(\mathrm{FeCl} 3)$, Folin ciocalteu reagent (FC reagent), TPTZ, pyrogallic acid (Sigma Germany). Methanol (HPLC gradient grade Merck Germany). Orthophosphoric Acid (OPA), RANKEM, Acetic acid (HPLC grade) was purchased from J. T. Baker (Netherlands). Milli-Q water was used in all experiments. Acetonitrl, Sodium Citrate, Sodium Hydroxide, Boric Acid Ethanol, Percholric Acid, Sodium Carbonate, Potassium Sulphate, Caprylic Acid, Mercapto Ethanol, Brij 35 solution, Sodium Hypochlorate, Tricarboxlyic Acid, Aspartic Acid, Threonine, Serine, Glutamic Acid, Proline, Glycine, Alanine, Cysteine, Valine, Methionine, Isoleucine, Leucine, Tyrosine, Phenyl Alanine, Histidine, Lysine, Arginine,Glutamic acid were purched from himedia.

\section{2 PLANT MATERIAL}

Various plant materials were obtained from western ghat region, India. Dried at $370 \mathrm{C}$ and stored in plastic bag in the dark atmosphere till use. Plant identification was conducted at the herbarium in the department of botany university of Pune and national botanical survey of India, Pune.

\section{3 Extraction of plant material}

The different parts of the various plants taken for the study were; Tridax procumbens (Leaves), Dendrophthoe falcate (Leaves), Withania somnifera (whole plant), Acacia catechu (root), Ricinus communis (root), Adhatoda zeylanica (Leaves), Acmella oleracea (root), Ficus religiosa (root) and Acorus calamus (whole plant) $1 \mathrm{gm}$ powder was mixed with $15 \mathrm{~mL}$ of methanol and kept slow strring for $24 \mathrm{~h}$. at 37 OC. Keeping the final volume were constants $15 \mathrm{~mL}$, The supernatant was collected after filtration.

\subsection{Phytochemicals Analysis}

\subsubsection{Analysis of Amino Acids}

The details of the methods are mentioned below as per the Shimadzu protocol ${ }^{9,10}$.

\section{Preparation of Mobile Phase}

Chemical Composition of Mobile Phase are mentioned in Table 2.

(Table 1: Chemical Composition of Mobile Phase of Amino acid analysis, Table 2: Preparation of Boric acid-Carbonic acid Buffer, pH 10 and Table 3: Preparation of fluorescence reaction Solution B (Ortho phthalaldehyde (OPA) solution $0.08 \%)$ )
Buffer additions were carried out to make it $500 \mathrm{ml}$ solution. Solution was stirred till crystals dissolve completely and filtered through $0.45 \mu$ membrane filter.

\section{Diluent preparation}

$0.2 \mathrm{~N} \mathrm{Na}+$ (sodium citrate), $\mathrm{pH} 2.20$

$9.8 \mathrm{~g}$ sodium citrate was dissolved in $400 \mathrm{ml}$ distilled water. To this made to addition of 8 $\mathrm{ml}$ perchloric acid and $0.05 \mathrm{ml} \mathrm{n}$-caprylic acid; distilled water was used to make $500 \mathrm{ml}$ solution. $\mathrm{pH} 2.20$ of solution adjusted by adding perchloric acid.

\section{Preparation of standard}

Different essential and non essential amino acid (Cysteine, Tyrosine, Glycine, Histidine, Arginine, Serine, Glutamic acid, Aspartic acid, Threonine, Methionine, Glutamic acid, Lysine, Alanine, Isoleucine, Leucine, Valine and Phenyl alanine) standard preparation was carried out in $4 \mathrm{ml}$ ethanol. From that $20 \mu \mathrm{L}$ of this filtered solution injected into the HPLC system.

\section{Instrumentation}

Name of Instrument: Shimadzu 20A instrument

Column: $\mathrm{Na}+$ type strongly acidic cation exchange resin Shim pack sodium column (ISC-07/S1504 Na). Detector: RF-10A XL SHIMADZU Fluorescence detector. Software: LC solution

Program set up for HPLC.

(Table 4: Gradient program for the HPLC for amino acid analysis)

The reagents were passed simultaneously for fluorescence reaction through HPLC column at the flow rate of $0.4 \mathrm{ml} / \mathrm{min}$ throughout the process, the reaction solution contains $0.2 \mathrm{ml}$ fluorescence reaction Solution $A$ and $0.2 \mathrm{ml}$ fluorescence reaction Solution B.

\section{Preparation of sample for amino acids analysis}

Different part of plant (1 - Tridax procumbens 2- Dendrophthoe falcate 3 -Withania somnifera 4 -Acacia catechu 5- Ricinus communis 6 Adhatoda zeylanica 7-Acmella oleracea 8 Ficus religiosa 9-Acorus calamus) powder $(1 \mathrm{gm})$ was mixed with $15 \mathrm{~mL}$ of Ethanol: Water (70:30) solvents reflux over a period of $2 \mathrm{hr}$. Then mixture was filtered through whatman filter paper Final volume was made to $15 \mathrm{~mL}$ in which $2.5 \mathrm{~mL}$ of $20 \%$ TCA was added and kept overnight at $4 \mathrm{OC}$. The extract 
is centrifuged and filter through whatman paper. $20 \mu \mathrm{L}$ filtrate was used for the analysis of essential and non-essential amino acids.

\subsubsection{Determination of polyphenolic content}

Total polyphenolic content was analyzed by the Folin-Ciocalteu method ${ }^{11}$. The reaction mixture $(3.6 \mathrm{~mL})$ contains $20 \mu \mathrm{L}$ of sample, 3.2 $\mathrm{ml}$ of distilled water, $100 \mu \mathrm{L}$ of FC reagent; 300 $\mu \mathrm{L}$ of $60 \mu \mathrm{g}$ of saturated sodium carbonate was incubated at $370 \mathrm{C}$ for $30 \mathrm{~min}$ in water bath the absorbance was read at $765 \mathrm{~nm}$ was measured in triplicate. Gallic acid $(100 \mu \mathrm{g} / \mathrm{mL})$ was used for calibration of standard curve. The results were expressed as $\mathrm{mg}$ of gallic acid equivalent (mg GAE)/g of dry plant material.

\subsubsection{Chromatographic analysis of polyphenolic and flavonoids}

A simple and quick reversed phase HPLC method used for determination of phenolic acids $^{12,13}$. Chromatographic analysis was with the use of liquid chromatographic system, which consisted of P680 HPLC Pump, ASI100 manual sample injector, thermostat column compartment C18, UVD170U detector. Chromatographic system was connected through the water universal chromatography interface to the computer. Software used for data acquisition and evaluation was Water. The separation was carried out on inertsil ODS $3 \mathrm{~V}, 250 * 4.6^{*} 5$ micron reversed phase column. Column temperature was maintained at $40^{\circ} \mathrm{C}$. Elution was performed by using gradient with the mobile phase consisting of mixture of buffer and acetonitrile (buffer 0.1M KH2PO4, PH 3.5 with OPA). Mobile phase A (buffer: ACN = 900:100), Mobile phase B (buffer: ACN $=450: 550$ ) and the flow rate was $1 \mathrm{ml} / \mathrm{min}$, with following gradient program

\section{(Table 2.1: Gradient program of solvent system for HPLC)}

The injection volume for all samples was $20 \mu \mathrm{L}$. For detection, chromatograms were monitored at $275 \mathrm{~nm}$. Identification of phenolic acids was based on retention times in comparison with standards. The quantification was carried out using the external standard method. Stock solution of standard compounds at concentration $1 \mathrm{mg} / \mathrm{ml}$ each was prepared in methanol. The solution of standards was injected into the HPLC system.

\subsection{Antioxidant Activity}

\subsubsection{Total antioxidant potential}

Total antioxidant potential of crude extract was determined by the Phosphomolybdate method $^{14}$. Final volume of the reaction 3.010 $\mathrm{ml}$ containing $3.0 \mathrm{ml}$ of $(0.6 \mathrm{M}$ sulfuric acid, $28 \mathrm{mM}$ sodium phosphate, and $4 \mathrm{mM}$ ammonium molybdate) $10 \mu \mathrm{L}$ of the respective extract incubated at $950 \mathrm{C}$ for $90 \mathrm{~min}$. After the samples were cooled at room temperature, the absorbance of the aqueous solution of each was measured at $695 \mathrm{~nm}$ against blank which contains $10 \mu \mathrm{L}$ of extracting solvent. Antioxidant potential of extracts were expressed as $\mathrm{mM}$ of Vit. C / $\mathrm{g}$ of dry plant material. The estimation was carried out in triplicate.

mg of Ascorbic acid $=\frac{(0 . D \text {. of Standard }-0 . D \text {. of Sample })}{(0 . D . \text { Standard })} \times$ Conc of Stdandard

\subsubsection{Ferric-reducing antioxidant potential assay}

The FRAP assay was carried out according to the procedure of Benzie and Strain with modification [15]. FRAP reagent was prepared from sodium acetate buffer (300 mMol/L, pH 3.6), $10 \mathrm{mMol} / \mathrm{L}$ TPTZ solution in $40 \mathrm{mMol} / \mathrm{L} \mathrm{HCl}$ and $20 \mathrm{mMol} / \mathrm{L}$ $\mathrm{FeCl} 3$ in $40 \mathrm{mMol} / \mathrm{L} \mathrm{HCl}$ solution in proportions of 10:1:1 (v/v), respectively. The FRAP reagent was stored in cooled condition at 0-4 $\mathrm{OC}$ for five days. Before use the reagent was warmed to $37^{\circ} \mathrm{C}$ in a water bath. $25 \mu \mathrm{L}$ of each extracts was added to $1.475 \mathrm{~mL}$ of sodium acetate buffer and $1.5 \mathrm{~mL}$ of FRAP reagent. The absorbance of the reaction mixture was then recorded at $593 \mathrm{~nm}$ after $5 \mathrm{~min}$. The standard curve was constructed using $\mathrm{FeSO} 4$ solution $(10-100 \mu \mathrm{Mol} / \mathrm{L})$. The results were expressed as $\mu \mathrm{Mol} \mathrm{Fe}(\mathrm{II}) / \mathrm{g}$ dry weight of sample.

$$
\mu \mathrm{M} \text { of } \mathrm{Fe}(\mathrm{II})=\frac{(0 . \mathrm{D} \text {.of Standard }-0 . \mathrm{D} \text {. of Sample })}{(0 . \mathrm{D} \text { Standard })} \times \text { Conc. of Standard }
$$

\subsubsection{Free radical scavenging ability by DPPH radical}

The DPPH assay was carried out by 96 well plate method ${ }^{16}$. DPPH assay is based on the measurement of the scavenging ability of antioxidants towards the stable DPPH radical. The free radical DPPH, which shows absorption at $517 \mathrm{~nm}$, is reduced to the corresponding hydrazine when it reacts with hydrogen donors. Stock solution of DPPH 1 $\mathrm{mM}$ was prepared in methanol and working solution $0.1 \mathrm{mM}$ prepared in methanol. $10 \mu \mathrm{L}$ of 1:4 diluted plant extract was added in $100 \mu \mathrm{L}$ of methanol and $100 \mu \mathrm{L}$ of $0.1 \mathrm{mMol}$ of DPPH. The mixture was shaken and allowed to stand at room temperature in the dark for $10 \mathrm{~min}$. The decrease in absorbance of the resulting solution was monitored at $517 \mathrm{~nm}$ at $10 \mathrm{~min}$. 
The results were expressed in \% of inhibition by following formula.

$\%$ of inhibition $=\frac{(0 . D . \text { of control }-0 . D . \text { of sample })}{(0 . D \text { control })} \times 100$

\section{RESULTS}

Antioxidants are complex chemicals (polyphenol, flavonols, chalcone minerals and other) found in plants ${ }^{11,16,29}$. Around 9 different types of plant sources were quantitiatively anlysed for the phytochemical (polyphenolics and flavonols) and antioxidant activities (FRAP, phosphomolybdate and DPPH). The result obtained from medicinal and vegetable were obtained are mentioned below.
Different amino acids (Cysteine, Tyrosine, Glycine, Histidine, Arginine, Serine Glutamic acid, Aspartic acid, Threonine, Methionine, Glutamic acid, Lysine, Alanine, Isoleucine, Leucine, Valine, Phenyl alanine) are determined by using amino acid analyzer. The quantities of 17 amino acids estimated are given in table 5. Essential amino acids are necessary for growth and maintains of the body. They cannot be synthesized by the human system. There are eight amino acids generally considered essential for adults while ten for children. Tyrosine and tryptophan are the precursors of neurotransmitters while Phenylalanine acts as analgesic and antidepressant $^{18,19,20}$. (Table 5: Conc. of free amino acids of different traditional medicinal plants).

\subsection{Phytochemicals analysis}

\subsubsection{Amino acids}

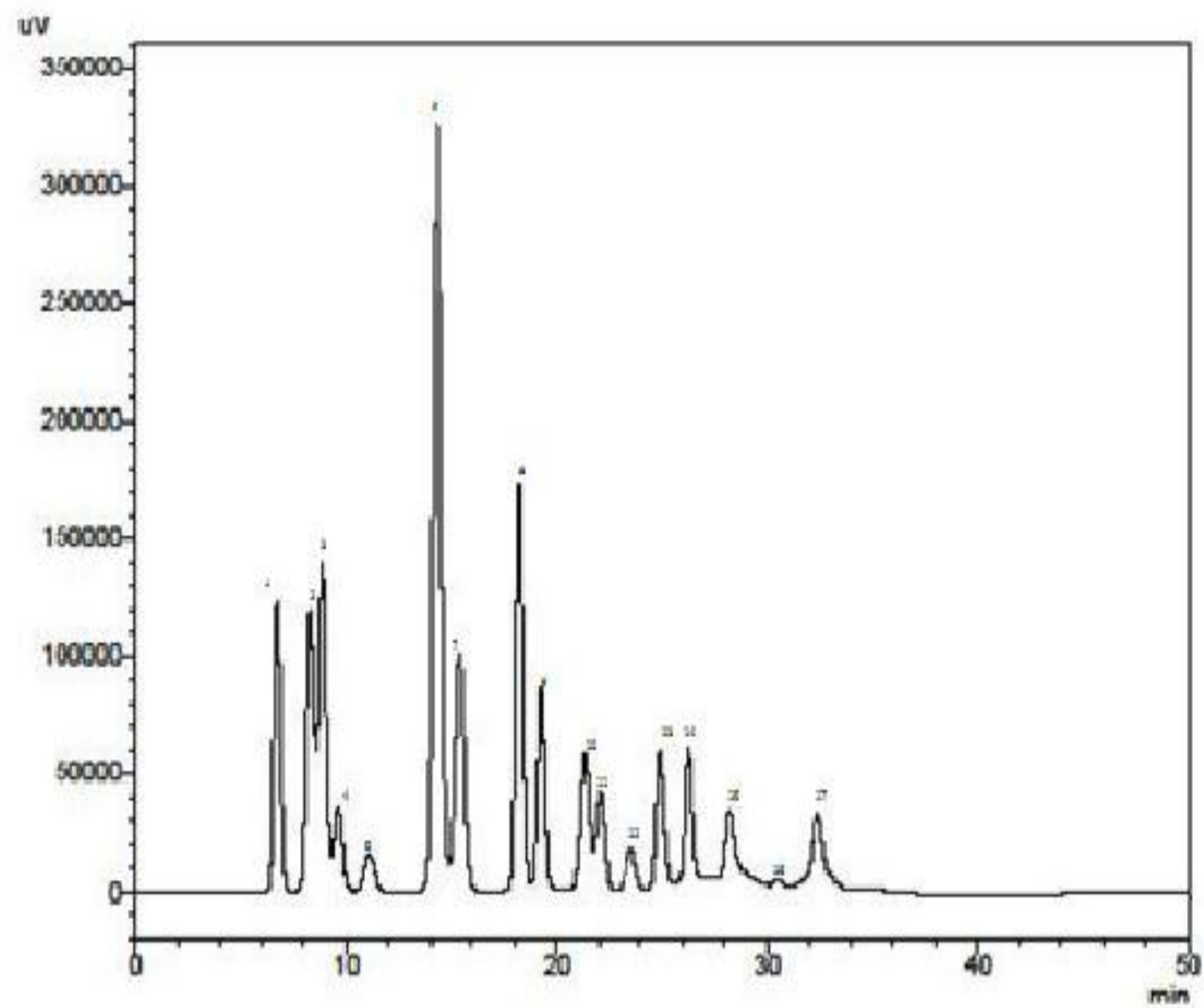

Spectra.1: Standard amino acid spectra of aspartic acid, threonine, serine, glutamic acid, proline, glycine, alanine, cysteine, valine, methionine, isoleucine, leucine, tyrosine, phenyl alanine, histidine, lysine, arginine and glutamic acid. 


\subsubsection{Total Phenolic Compounds}

Results obtained from the analysis of polyphenolics are mentioned in Fig -1 . The amounts of phenolic compounds are varied from plant to plant. Among all of the extracts, the highest amount was found in the Dendrophthoe falcate and Acorus calamus
(22.43 and $19.27 \mathrm{mg}$ gallic acid / $\mathrm{g}$ of sample) plant extracts were as the lowest amount was measured in the Withania somnifera extract (6.36 mg gallic acid / $\mathrm{g}$ of sample). (Fig. 1: Polyphenolic contents of medicinal plants extract)

\subsubsection{Chromatographic analysis of polyphenolic and flavonoids}

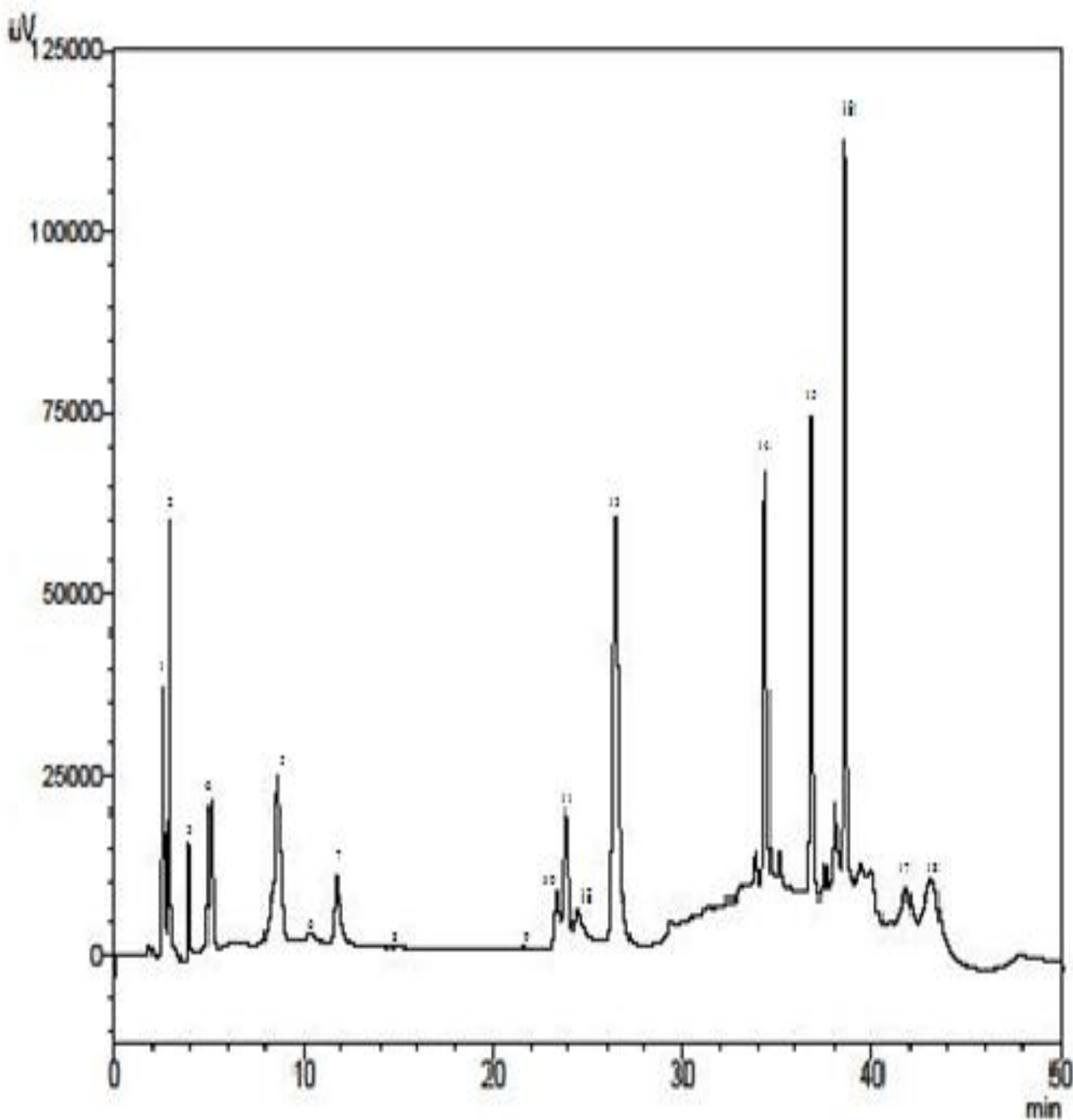

Spectra. 2: Chlorogenic acid, imidazol, gallic acid, quinine, hydraquinone, catachin hydrate, vanillin, epigallacto catechin, rutin, naringenin, quercetin, naringin, couymarin, indole, 2-methyl napthaquinone, hydorxy diphenyl phenol, cucumin, quinoline, tannic acid standard HPLC spectra 
Phytochemicals such as flavonoids (quercetin, naringenin, naringin and rutin) and polyphenolics (gallic acid, epigallactocatechin and curcumin) were determined by HPLC (Table 6 ). Acorus calamus, Ficus religiosa and Acmella oleracea contained higher level of flavonoids likes Quercetin, Rutein, Naringenin, and naringin shown in Table-6 (Table 6: Analysis of Phytochemicals $(\mu \mathrm{g} / \mathrm{gm}$ dry wt.)

of different traditional medicinal plants by HPLC).

\subsection{Antioxidant Activity}

\subsubsection{Total antioxidant potential}

Medicinal plant methanol extracts (1-9) were evaluated for their phosphomolybdate antioxidant potential activity. Results are compared with the standard ascorbic acid. All plants showed phosphomolybdate antioxidant potential (Fig. 2: Total antioxidant activity of medicinal plants extract).

The methanol extract of plant Dendrophthoe falcate and Acorus calamus (13.198 and 9.926 $\mathrm{mM}$ of ascorbic acid/ gm of sample) was found to exhibit the highest antioxidant activity, followed by Tridax procumbens and Withania somnifera activity as compare to Acacia catechu, Ricinus communis, Acmella oleracea, Adhatoda zeylanica and Ficus religiosa.

\subsubsection{Ferric-reducing antioxidant potential} The antioxidant potential of methanol extracts for plants part were estimated from their ability to reduce TPTZ-Fe(III) complex to TPTZ-Fe(II).The reducing ability of the medicinal plant extracts Acmella oleracea, Adhatoda zeylanica, Ricinus communis, Acorus calamus, Ficus religiosa, Acorus calamus and Dendrophthoe falcate was higher than that of the other extracts (Fig 3). The FRAP value of the various extract was shown in fig 3. (Fig. 3: Ferric reducing antioxidant potential of medicinal plants extract)

\subsubsection{DPPH radical}

DPPH assay is considered a valid and easy assay to evaluate the radical scavenging activity of antioxidants. Medicinal plants Dendrophthoe falcate, Ficus religiosa and Acorus calamus showed maximum radical scavenging ability (Fig. 4: Radical scavenging antioxidant activity of medicinal plants extract).

Table 1: Chemical Composition of Mobile Phase of Amino acid analysis

\begin{tabular}{|c|c|c|}
\hline Chemical & Liquid A & Liquid B \\
\hline Sodium Normality (N) & 0.2 & $0.6+\alpha($ about 0.1$)$ \\
pH & 3.2 & 10.0 \\
\hline Sodium citrate.2H2O (g) & 58.8 & 58.8 \\
\hline Sodium hydroxide $(\mathrm{g})$ & - & - \\
\hline Boric Acid (g) & - & 12.4 \\
\hline Ethanol (99.5\%) (ml) & 210 & - \\
\hline Perchloric Acid (60\%) (ml) & 50 & - \\
\hline 4N NaOH (ml) & - & 30 \\
\hline Final Volume (liter) & 3 & 1 \\
\hline
\end{tabular}

Liquid $A$ and $B$ filtered through $0.45 \mu$ membrane filter.

Preparation of fluorescence reaction reagent

Preparation of Boric acid-Carbonic acid Buffer, $\mathrm{pH} 10$ mentioned in table 2.3.

Table 2: Preparation of Boric acidCarbonic acid Buffer, pH 10

\begin{tabular}{|c|c|c|}
\hline Chemical & Quantity (g) & Molarity (M) \\
\hline Sodium Carbonate & 122.20 & 0.384 \\
\hline Boric acid & 40.70 & 0.216 \\
\hline Potassium Sulphate & 56.40 & 0.108 \\
\hline
\end{tabular}

Above reagent were dissolved in water to make 3.0 liter solution. $\mathrm{pH}$ adjusted to 10 . Brij-35 (polyoxyethylene lauryl ether) Solution (10\%) Preparation of fluorescence reaction Solution $\mathrm{A}$ (Sodium hypochlorite $(\mathrm{NaClO})$ solution) $0.2 \mathrm{ml}$ commercially available sodium hypochlorite aqueous solution was added to $500 \mathrm{ml}$ boric acidcarbonic acid buffer. The solution was mixed thoroughly and filtered through $0.45 \mu$ membrane filter. 
Table 3: Preparation of fluorescence reaction Solution B

(Ortho phthalaldehyde (OPA) solution $\mathbf{0 . 0 8 \%}$ )

\begin{tabular}{|c|c|}
\hline Chemical & Quantity \\
\hline OPA & $400 \mathrm{mg}$ \\
\hline Ethanol & $7.0 \mathrm{ml}$ \\
\hline 2- Mercaptoethanol & $1.0 \mathrm{ml}$ \\
\hline $10 \%$ Brij -35 solution & $2.0 \mathrm{ml}$ \\
\hline
\end{tabular}

Table 4: Gradient program for the HPLC for amino acid analysis

\begin{tabular}{|c|c|c|c|}
\hline Time (min) & $\begin{array}{c}\text { Conc. of } \\
\text { mobile phase } \\
\text { A (\%) }\end{array}$ & $\begin{array}{c}\text { Conc. of } \\
\text { mobile phase } \\
\text { B (\%) }\end{array}$ & Flow rate \\
\hline 9.00 & 100 & 0 & 0.6 \\
\hline 13.00 & 93 & 7 & 0.6 \\
\hline 17.20 & 92 & 8 & 0.6 \\
\hline 17.21 & 89 & 11 & 0.6 \\
\hline 20.80 & 89 & 11 & 0.6 \\
\hline 20.81 & 50 & 50 & 0.6 \\
\hline 22.00 & 42 & 58 & 0.6 \\
\hline 22.01 & 000 & 100 & 0.6 \\
\hline 29.30 & 000 & 100 & 0.6 \\
\hline 29.31 & 100 & 000 & 0.0 \\
\hline 35.00 & 100 & 000 & 0.6 \\
\hline 36.50 & 100 & 000 & 0.7 \\
\hline 43.30 & 100 & 000 & 0.7 \\
\hline 44.00 & 100 & 000 & 0.6 \\
\hline 60.00 & Stop & Stop & Stop \\
\hline & & & \\
\hline
\end{tabular}

Table 2.1: Gradient program of

solvent system for HPLC

\begin{tabular}{|c|c|c|}
\hline Time in Min & Mobile Phase A & Mobile Phase B \\
\hline 00 & 95 & 05 \\
\hline 08 & 95 & 05 \\
\hline 20 & 50 & 50 \\
\hline 35 & 44 & 56 \\
\hline 45 & 44 & 56 \\
\hline 50 & 10 & 90 \\
\hline 75 & 10 & 90 \\
\hline 80 & 95 & 05 \\
\hline 90 & 95 & 05 \\
\hline
\end{tabular}

Table 5: Conc. of free amino acids of different traditional medicinal plants

\begin{tabular}{|c|c|c|c|c|c|c|c|c|c|}
\hline & $\begin{array}{c}\text { Acacia } \\
\text { catechu } \\
\mu \mathrm{g} / \mathrm{gm}\end{array}$ & $\begin{array}{l}\text { Dendrophthoe } \\
\text { falcate } \mu \mathrm{g} / \mathrm{gm}\end{array}$ & $\begin{array}{c}\text { Withania } \\
\text { somnifera } \\
\mu \mathrm{g} / \mathrm{gm}\end{array}$ & $\begin{array}{c}\text { Ricinus } \\
\text { communis } \\
\mu \mathrm{g} / \mathrm{gm}\end{array}$ & $\begin{array}{c}\text { Tridax } \\
\text { procumbens } \\
\mu \mathrm{g} / \mathrm{gm}\end{array}$ & $\begin{array}{c}\text { Acmella } \\
\text { oleracea } \\
\mu \mathrm{g} / \mathrm{gm}\end{array}$ & $\begin{array}{l}\text { Ficus } \\
\text { religiosa } \\
\mu \mathrm{g} / \mathrm{gm}\end{array}$ & $\begin{array}{c}\text { Adhatoda } \\
\text { zeylanica } \\
\mu \mathrm{g} / \mathrm{gm}\end{array}$ & $\begin{array}{c}\text { Acorus } \\
\text { Calamus } \\
\mu \mathrm{g} / \mathrm{gm}\end{array}$ \\
\hline Aspartic acid & 0.069 & 0.000 & 0.879 & 0.287 & 0.381 & 0.244 & 0.067 & ND & ND \\
\hline Threonine & 0.282 & 0.488 & 4.182 & 0.375 & 2.744 & 0.279 & 12.038 & 0.065 & 0.337 \\
\hline Serine & 0.176 & 0.100 & 1.115 & 0.455 & 1.045 & ND & ND & ND & ND \\
\hline Glutamic acid & 0.192 & 1.516 & 0.908 & 0.627 & 2.516 & 0.147 & ND & ND & 0.169 \\
\hline Proline & 0.485 & 2.586 & 92.771 & 1.786 & 3.535 & 0.537 & 0.279 & 0.674 & 0.397 \\
\hline Glycine & 0.007 & 0.071 & 0.348 & 0.168 & 0.090 & 0.012 & 0.008 & 0.007 & 0.011 \\
\hline Alanine & 1.200 & 0.240 & 0.862 & 0.163 & 1.396 & 0.018 & 0.168 & 0.020 & 0.476 \\
\hline Cystine & 0.621 & 2.455 & 5.244 & 1.895 & 2.440 & 0.206 & 0.141 & 0.156 & 0.060 \\
\hline Valine & 1.855 & 0 & 6.169 & 3.154 & 2.557 & 0.226 & 0.333 & 0.271 & 0.132 \\
\hline Methionine & 0.990 & 1.356 & 3.289 & 0.000 & 1.987 & 0.155 & ND & 0.066 & ND \\
\hline Iso- leucine & 6.911 & 3.281 & 26.062 & 7.973 & 10.468 & 0.175 & ND & ND & ND \\
\hline Leucine & 21.666 & 3.086 & ND & ND & ND & 1.260 & 2.773 & 0.647 & 16.267 \\
\hline Tyrosine & 24.869 & 14.654 & 27.258 & 15.765 & 17.520 & 1.006 & 0.935 & 0.448 & 1.568 \\
\hline Histidine & 0.000 & 113.299 & 92.106 & 100.178 & 88.295 & ND & ND & ND & ND \\
\hline Lysine & ND & 645.056 & ND & ND & ND & 23.109 & 28.638 & 32.250 & 17.848 \\
\hline Arginine & 69.418 & 61.111 & 36.908 & 66.752 & 31.338 & ND & ND & ND & 8.109 \\
\hline
\end{tabular}


Table 6: Analysis of Phytochemicals ( $\mu \mathrm{g} / \mathrm{gm}$ dry wt.) of different traditional medicinal plants by HPLC

\begin{tabular}{|c|c|c|c|c|c|c|c|c|c|}
\hline $\begin{array}{c}\text { Plants } \\
\text { Compounds }\end{array}$ & $\begin{array}{c}\text { Tridax } \\
\text { procumbens }\end{array}$ & $\begin{array}{l}\text { Dendrophthoe } \\
\text { falcate }\end{array}$ & $\begin{array}{l}\text { Ficus } \\
\text { religiosa }\end{array}$ & $\begin{array}{l}\text { Adhatoda } \\
\text { zeylanica }\end{array}$ & $\begin{array}{c}\text { Acacia } \\
\text { catechu }\end{array}$ & $\begin{array}{l}\text { Acmella } \\
\text { oleracea }\end{array}$ & $\begin{array}{l}\text { Withania } \\
\text { somnifera }\end{array}$ & $\begin{array}{l}\text { Ricinus } \\
\text { communis }\end{array}$ & $\begin{array}{l}\text { Acorus } \\
\text { Calamus }\end{array}$ \\
\hline Quinone & 417.27 & ND & 232.94 & 547.9 & ND & 261.44 & 251.8 & 28.45 & 1527 \\
\hline Quercetin & 392.30 & 143.04 & 566.98 & 280.96 & ND & 380.8 & 32.78 & ND & 672.52 \\
\hline Naringin & 408.76 & 149.08 & 590.93 & 292.83 & ND & 396.88 & 34.16 & ND & 700.59 \\
\hline Naringenin & 56.24 & 48.87 & 92.66 & 60.57 & 7.12 & 112.64 & 12.42 & 18.47 & 4.607 \\
\hline Rutein & 198.06 & 240.12 & 413.8 & 573.08 & $\mathrm{ND}$ & 237.17 & 120.08 & 11.91 & 207.34 \\
\hline Chlorogenic acid & 28.92 & 64.5 & 75.78 & 48.48 & 32.6 & 10.01 & 89.2 & 22.18 & 2278 \\
\hline Gallic acid & 50.65 & 94.98 & 174.02 & 392.32 & 157.62 & 135.32 & 107.22 & 13.17 & ND \\
\hline $\begin{array}{l}\text { Epigallacto } \\
\text { Catechin }\end{array}$ & 284.08 & ND & 66.98 & 233.12 & ND & 570.78 & ND & 36.35 & 36.04 \\
\hline Curcumin & 246.14 & 22.5 & 545.84 & 111.78 & 348.23 & 197.17 & 310.8 & 254.4 & 50.88 \\
\hline
\end{tabular}

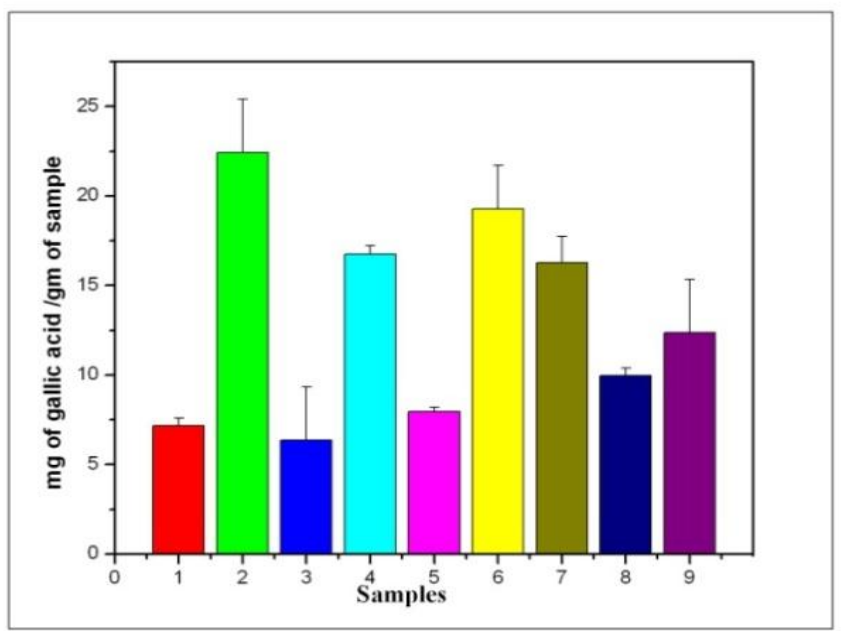

Fig. 1: Polyphenolic contents of medicinal plants extract

1 - Tridax procumbens 2- Dendrophthoe falcate 3 -Withania somnifera 4 -Acacia catechu 5- Ricinus communis 6 -Adhatoda zeylanica 7 -Acmella 8 -Ficus religiosa 9- Acorus calamus. $n$ (sample size) $=3$.

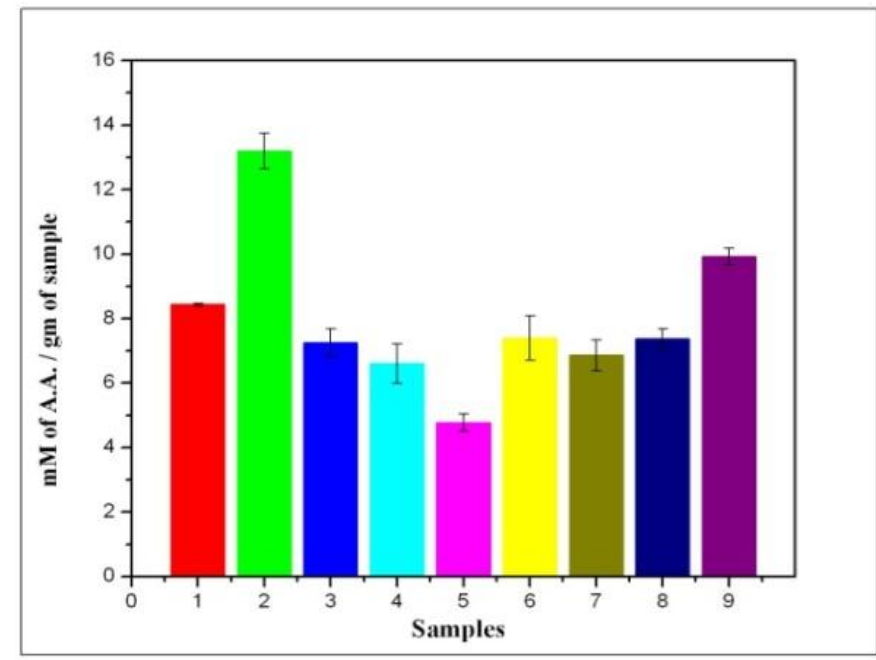

Fig. 2: Total antioxidant activity of medicinal plants extract

1 - Tridax procumbens 2- Dendrophthoe falcate 3 -Withania somnifera 4 -Acacia catechu

5- Ricinus communis 6 -Adhatoda zeylanica 7 Acmella oleracea 8 -Ficus religiosa 
9- Acorus calamus. Data are shown as mean \pm S.D.

one way ANOVA $p=<0.001$ which represents the significance $n$ (sample size) $=3$.

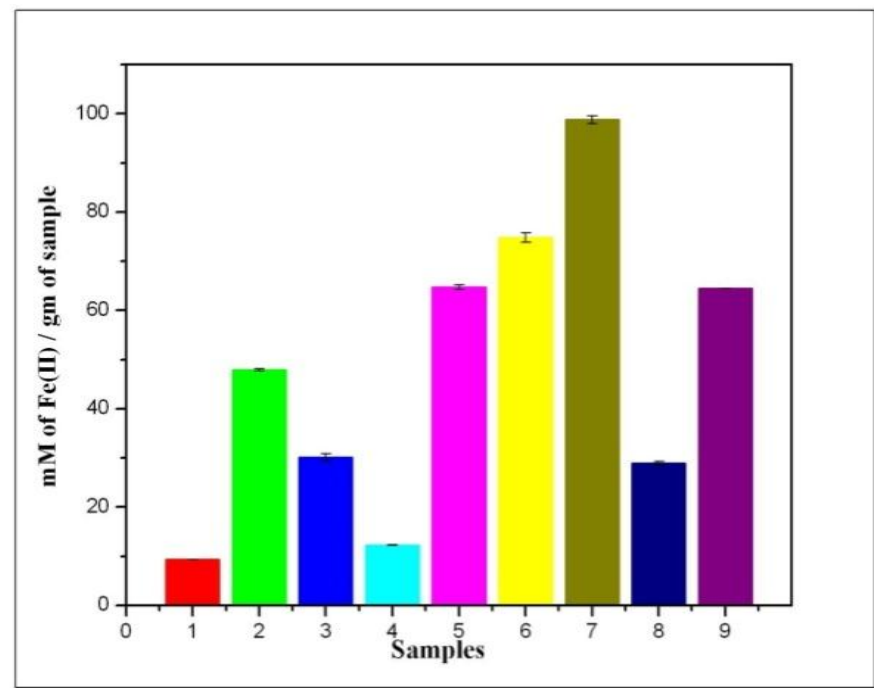

Fig. 3: Ferric reducing antioxidant potential of medicinal plants extract

1 - Tridax procumbens 2- Dendrophthoe falcate 3 -Withania somnifera 4 -Acacia catechu 5- Ricinus communis 6 -Adhatoda zeylanica 7 - Acmella oleracea 8 -Ficus religiosa 9- Acorus calamus. Data are shown as mean \pm S.D.

one way ANOVA $p=<0.001$ which represents the significance, $n$ (sample size $)=3$.

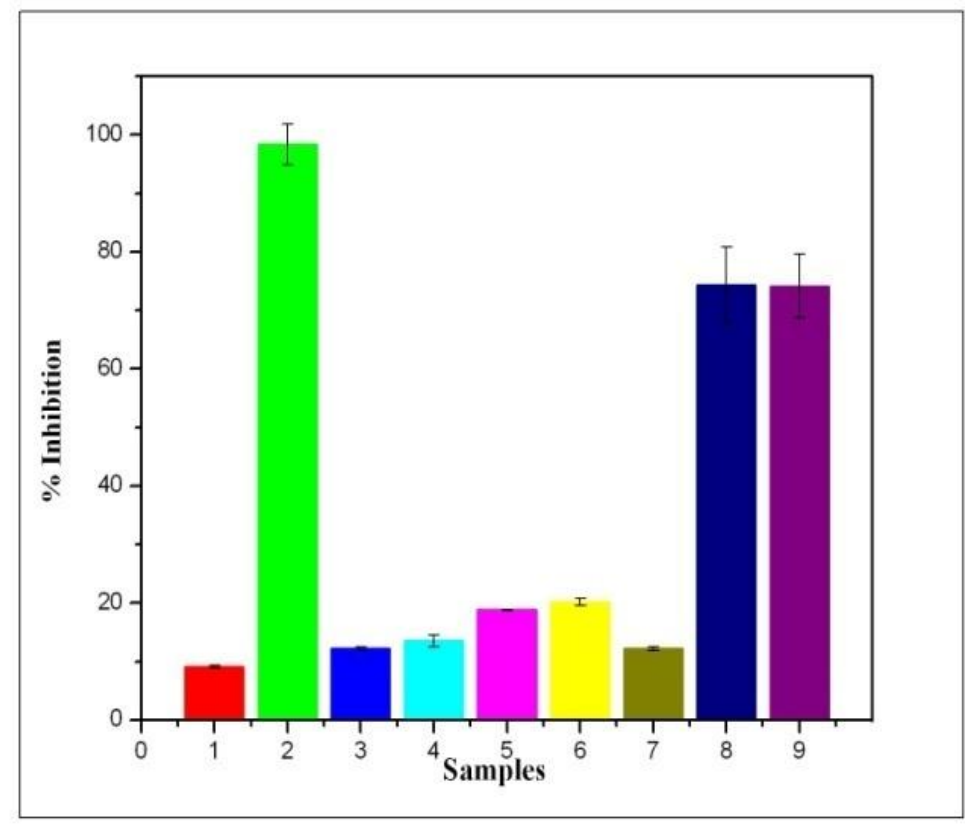

Fig. 4: Radical scavenging antioxidant activity of medicinal plants extract

1 - Tridax procumbens 2- Dendrophthoe falcate 3 -Withania somnifera 4 -Acacia catechu 5- Ricinus communis 6 -Adhatoda zeylanica 7- Acmella oleracea 8 -Ficus religiosa 9- Acorus calamus. Data are shown as mean $\pm S$.D.

one way ANOVA $p=<0.001$ which represents the significance, $n$ (sample size) $=3$. 


\section{DISCUSSION}

The presence of different antioxidant components in the plant tissues makes it relatively hard to quantify each antioxidant component separately. The antioxidant activity of phenolics is mainly due to their redox properties which make them act as reducing as agents, hydrogen donors, and singlet oxygen quenchers. They also may have a metal chelating potential.

The unclear relationship between the antioxidant activity and the total phenolics may be explained in numerous ways, in fact, the total phenolics content incorporate all the antioxidants $^{11,16,17}$. In addition, the synergism between the antioxidants in the mixture makes the antioxidant activity not only dependant on the concentration, but also on the structure and the interaction between the antioxidants. This is the reason why samples such as Tridax procumbens, Withania somnifera and Ricinus communis with similar concentrations of total phenolics, may vary in their antioxidant activities. The results suggest that the phenolic compounds contribute significantly to the antioxidant capacity of the medicinal plants.

Antioxidant activity of phenolics mainly depends on the number and the position of hydrogen-donating hydroxyl groups on the aromatic cycles of the phenolic molecules ${ }^{11}$. It has been shown that the presence of the $\mathrm{CH}=\mathrm{CH}, \mathrm{COOH}, \mathrm{OH}$ and phenyl group in the polyphenolics ensures greater $\mathrm{H}$-donating ability and subsequent radical stabilization ${ }^{21,22}$.

\section{CONCLUSION}

The purpose of this study was the evaluation of the antioxidant capacity and phenolic compounds of medicinal plants. These medicinal plants showed stronger antioxidant activity and phenolics content than the common nutritional plants. It has been also noted in this study that these plants are strong radical scavengers and can be considered as good sources of natural antioxidants for medicinal and commercial uses. However, due to the diversity and complexity of the natural mixtures of phytochemical compounds in these plant extracts, it is not easy to characterize every compound and assess their antioxidant activities. Each plant contains generally different phytochemical compounds with different amount of antioxidant activity. Upon this study, we can state that more pharmacological studies are needed to further confirm the advantageous quality of these extracts.

\section{REFERENCES}

1. Brewer MS. Natural Antioxidants: Sources, Compounds, Mechanism of Action and Potential Applications Comprehensive Reviews in food Science And food Safety. 2011;10:221-247.

2. Agustyniak A, Bartosz G, Cipak A, Duburs G, Horakova L, Luczaj W, Majekova M, Oddesseos AD, Rackova L, Skrzydlewska E, Stefek M, Strosova M, Tirzities G, Venskutonis PR, Viskupicova J, Vraka PS and Zarkovic N. Natural And Synthetic antioxidants: and update overview. Free Radic Res. 20101;44:1216-1262.

3. Liu R, Ruan $T$, Songs $S$, Lin $Y$ and Jiang G. Determination of synthetic phenolic Antioxidants and relative metabolites in sewage treatment plant and recipient river by high performance liquid chromatographyelectrospray tandem mass spectrometry. J Chromatogr A. 2015;13:13-21.

4. Rodil R, Quintana JB and Cela R. Oxidation of synthetic phenolic antioxidants during water chlorination, J Hazard Mater. 2012;15:73-81.

5. Andrade JM and Fasolo D. Chapter 20- Polyphenol Antioxidants from natural sources and contribution to Health promotion polyphenols in Human Health and Disease. 2014;1:253-265.

6. Kaliora AC and George VZ. Dedoussis, Natural Antioxidants Compound in risk factor of CVD, Pharmacology research. 2007;56:99109.

7. Bansal P, Mudgal J, Nayak PG, Pannakal ST, Priyadarsini KI and Unnikrishnan MK. Antidiabetic, antihyperlipidemic and antioxidant effects of the flavonoid rich fraction of pilea microphylla (L.) in high fat diet/streptozotocin-induced diabetes in mice, Experimental and Toxicologic pathology. 2012;64:651-658.

8. Martinez-Dominguez $D$, Heras MA, Navarro $\mathrm{F}$ and Torronteras RF. Efficiency of antioxidant response in spartina densiflora: An adaptative success in a polluted environment, Environmental and Experimental Botony. 2008;62:69-77. 
9. Shimadzu protocol for amino acid analysis. 1-60.

10. Ishida $Y$, Fujita $T$ and Asai K. Report J chromatography. 1981;204.

11. 11a) Fukumoto LR, Mazza G, Assessing antioxidant and prooxidant activities of phenolic compounds. J Agric Food Chem. 2000;48:35973604. 11b). Lehninger AL. Principle of biochemistry. 2nd edition, worth publisher Inc. pvt. Ltd. New York

12. Klejdus B, Mikelova R, Petrloa J, Potesil D, Adam V, Stiborova M, Hodek P, Vacek J, Kizek R and Kuban V. Determination of isoflavones in soy bits by fast column highperformance liquid chromatography coupled with UV-visible diode-array detection, Journal of Chromatography A. 2005;1084:71-79.

13. Rostagno MA, Palma $M$ and Barroso CG. Fast analysis of soy isoflavones by high-performance liquid chromatography with monolithic columns, Analytica Chimica Acta. 2007;582:243-249.

14. Germano MP, Pasquale DER, Angelo V, Catania S, Silvaria V and Costa C. Evaluation of extracts and isolated fraction from Capparis spinosa $\mathrm{L}$. Buds as an antioxidant source. J Agric Food Chem. 2002;50:1168-1171.

15. Benzie IFF and Strain JJ. The ferric redicing ability of plasma as a measure of antioxidant power the FRAP assay. Analytical Biochemistry. 1996;239:70-76.

16. Bozin B, Mimica-Dukic N, Samojlik I, Goran A and Igic R. Phenolics as antioxidants in garlic (Allium sativum L., Alliaceae), Food Chemistry. 2008;111: 925-929.

17. Adedapo AA, Jimoh FO, Koduru S, Masika PJ and Afolayan AJ. Evaluation of the medicinal potentials of the methanol extracts of the leaves and stems of Halleria lucida, Bioresource Technology. 2008;99:4158-4163.

18. Beckmann $\mathrm{H}$, Athen $\mathrm{D}$, Olteanu $\mathrm{M}$ and Zimmer R. dl-Phenylalanine versus imipramine: A double-blind controlled study. European Archives of Psychiatry and Clinical Neuroscience. 1979;227:49-58.

19. Meyers S. Use of neurotransmitter precursors for treatment of depression. Altern Med Rev. 2000;5:71-64.

20. Beckmann $\mathrm{H}$, Athen $\mathrm{D}$, Olteanu $\mathrm{M}$ and Zimmer R. dl-Phenylalanine versus imipramine: A double-blind controlled study. European Archives of Psychiatry and Clinical Neuroscience. 1979;227:49-58.

21. Rice-Evans CA, Miller NJ and Paganga G. Structure - antioxidant activity relationships of flavonoids and phenolic acids. Free Radical Biology and Medicine. 1996;20:933-956.

22. Heim KE, Tagliaferro AR and Bobilya DJ. Flavonoids antioxidants: chemistry, metabolism and structureactivity relationships. The Journal of Nutritional Biochemistry. 2002;13:572584. 